$$
\begin{aligned}
& \text { 담수순화 감성돔 Acanthopagrus schlegeli의 } \\
& \text { 생식소발달, 성 스테로이드호르몬 및 채정시기 }
\end{aligned}
$$

정민환·임한규 ${ }^{1}$ 김영수 ${ }^{2} \cdot$ 김수연 ${ }^{2} \cdot$ 장영진 ${ }^{2 *}$

국립수산과학원 양식관리과, ${ }^{1}$ 국립수산과학원 서해수산연구소,

${ }^{2}$ 부경대학교 해양바이오신소재학과

\title{
Sperm Collection Time, Sex Steroid Hormones, and Gonadal Development of Black Porgy, Acanthopagrus schlegeli, Acclimated in Freshwater
}

\author{
Min Hwan Jeong, Han Kyu Lim', Young Soo Kim², \\ $\mathrm{Su}$ Yeon $\mathrm{Kim}^{2}$ and Young Jin Chang'* \\ Aquaculture Management Division, National Fisheries Research and \\ Development Institute, Busan 619-902, Korea \\ ${ }^{1}$ West Sea Fisheries Institute, National Fisheries Research and \\ Development Institute, Taean 357-945, Korea \\ ${ }^{2}$ Department of Marine Bio-materials and Aquaculture, \\ Pukyong National University, Busan 608-737, Korea
}

The sperm collection time, sex steroid hormones, and gonadal development of protandrous black porgy, Acanthopagrus schlegeli, acclimated in freshwater for more than 2 years were investigated to evaluate its reproductive capability. The gonadal development of black porgy reared in seawater and freshwater could each be classified into four successive stages. For black porgy reared in seawater (BSW) as the control, these were the growing (December to February), mature (February to March), spent (March to June), and degeneration and resting (July to December) stages; for black porgy reared in freshwater (BFW), these were the growing (November to January), mature (January to February), spent (February to May), degeneration and resting (June to November) stages. In both BSW and BFW, the plasma cortisol levels were the highest in March. The plasma testosterone (T) levels of BSW and BFW were the highest in March and February, respectively. The plasma estradiol-17 $\beta\left(\mathrm{E}_{2}\right)$ levels did not differ significantly between BSW and BFW. The 11-ketotestosterone (11-KT) levels in the plasma of BSW and BFW were the highest in April. Sperm was collectible from March to June in BSW and from February to May in BFW. The results indicated that the gonadal maturation of BFW was about 1 month faster than that of BSW.

Key words: Black porgy, Acclimated freshwater, Gonadal development, Sex steroid hormones, Sperm collection time

$$
\text { 서 론 }
$$

최근 광범위한 염분내성을 가지고 있는 어류의 특성을 이용 하여 친환경 양식에 활용하려는 연구가 추진되고 있다. 이러 한 광염성 어류 중 숭어 Mugil cephalus, 감성돔 Acanthopagrus schlegeli, 농어 Lateolabrax japonicus 및 강도다리 Platichthys stellatus는 해수에서 담수로 순화시켜 저염분 양식을 위한 연구 (Chang et al., 1996; Min et al., 2003; Han et al., 2003; Kim et al., 2009)가, 이와 반대로 틸라피아 Oreochromis sp.와 무지개송어 Oncorhynchus mykiss 는 담수에서 해수로 순화시 켜 고염분 양식을 위한 연구가 이루어진 바 있다 (Chang and Hur, 1999; Choe and Yeo, 2002). 이와 같이 어종별 고유의 염분범위를 벗어난 저염분 및 고염분 순화사육은 담수어에서 특유의 냄새 성분을 제거하여 사육어의 상품성을 향상시키고,

\footnotetext{
*Corresponding author: yjchang@pknu.ac.kr
}

부족한 내수면 양식장의 입지조건을 완화시킬 수 있다 (Yoon et al., 1996). 또한 해수어에서는 적조발생시 해수에서 담수로 일시적 또는 장기적으로 옮겨 사육함으로써 적조 피해를 최소 화할 수 있으며, 저염분에 내성이 약한 해산 기생충 및 세균 구제 등 삼투압 충격을 이용한 질병치료도 가능하다 (Min et al., 2006a).

감성돔의 저염분 양식방법의 개발에 대하여는 Chang et al. (2002)이 감성돔 치어를 이용하여 급격한 염분변화에 따른 혈액생리학적 변화를 연구한 뒤, 담수순화 과정에서 나타나는 스트레스 반응, 삼투압조절 능력 및 mRNA 발현, 담수사육에 따른 혈액, 내분비 및 산소소비 등 분자 - 생리 - 생태학적 연 구가 진행된 바 있다 (Min et al., 2003, 2005a; Jeong et al., 2007; Chang et al., 2007; Choi et al., 2007). 또한 담수순화 사육한 감성돔의 생리활성 촉진을 위한 갑상선호르몬의 내분 비학적 연구와 감성돔의 저염분 양식산업화를 위한 어육평가 
및 수익성분석 결과가 보고되기도 하였다 (Min et al., 2006b, 2006c). 이렇게 감성돔의 저염분 양식을 위한 연구가 활발히 진행되고 있으나, 보다 안정적이고 완전한 저염분 양식을 위 해서는 저염분 환경에 장기간 사육하면서 생리 - 생태학적 조건을 포함한 번식생리학적 연구가 더 필요하다.

해산 경골어류인 감성돔이 저염분 환경에 완전히 적응하여 성장과 생리활성이 정상적이라 하더라도, 환경수의 염분변화 는 생식 및 내분비계 호르몬의 활성과 분비에 교란을 주어 생식소발달, 성 성숙, 산란 및 성 전환 등 생식활동에 영향을 줄 수 있으며, 배우자 (정자, 알)의 질 및 특성 등 번식능력에 영향을 미칠 수 있다. 또한 저염분 양식 중 감성돔이 강, 댐 및 호수 등의 자연계로 유출되었을 때, 먹이사슬의 교란, 우점 종의 변화 등 담수 생태계에 영향을 줄 수 있으므로 이 종에 대한 담수환경에서의 생식 및 번식 가능성을 타진할 필요가 있다.

따라서, 본 연구에서는 2 년 이상 장기간 담수순화 사육한 3 년생 담수사육 감성돔 $(\mathrm{BFW})$ 의 생식소 발달과 번식기간동 안 성 스테로이드호르몬 변화, 채정시기 및 채정량 등을 해수 사육 감성돔 $(\mathrm{BSW})$ 과 비교 - 분석하여 장기간 담수사육한 감 성돔의 생식활동 및 번식생리학적 변화를 알아보고자 하였다.

\section{재료 및 방법}

\section{실험어 및 담수순화}

실험에 사용한 감성돔은 해수 및 담수 순환여과 사육수조에 서 장기간 실내사육한 3 년생 감성돔 60 마리 $(\mathrm{BSW}$ : 전장 $28.2 \pm 2.0 \mathrm{~cm}$, 체중 $331.5 \pm 121.0 \mathrm{~g}, 30$ 마리; $\mathrm{BFW}$ : 전장 $27.0 \pm 1.9$ $\mathrm{cm}$, 체중 $348.5 \pm 111.6 \mathrm{~g}, 30$ 마리)를 사용하였다. BFW은 $\mathrm{Min}$ et al. (2003)의 담수순화 방법을 이용하여 해수에서 사육중인 감성돔을 $10 \mathrm{psu}$ 의 해수에서 24시간 동안 안정시킨 후, 완전담 수로 옮겨 사육하였다. 이러한 방법으로 담수순화시킨 감성돔 을 2년 이상 (3년생) 담수 순환여과수조에서 사육한 다음 실험 에 사용하였다.

\section{생식소 발달}

월별 생식소 발달상태를 조사하기 위한 생식소중량지수 (gonadosomatic index: GSI)는 생식소 중량 $\times 100 /$ 어체중의 식에 의하여 계산하였다. 그리고 감성돔의 정소 및 난소조직의 발 달단계를 조사하기 위하여 Bouin액에 고정된 생식소를 상법 에 따라 파라핀으로 포매한 다음, 조직을 $5 \mu \mathrm{m}$ 두께로 연속절 편하고, haematoxylin-eosin (H-E)으로 대비염색하여 광학현미 경으로 관찰하였다. 또한 생식소 발달단계를 성장기, 성숙기, 방정기 그리고 퇴화 및 휴지기의 4단계로 구분하여 생식주기 를 판정하였다.

\section{채정 및 Spermatocrit}

실험어로부터 정액을 채취하기 이전에 배설물에 의한 정액 오염을 방지하기 위하여 채정 24시간 전부터 절식시켰다. 정 액을 채취하기 위하여 실험어를 $200 \mathrm{ppm}$ 2-phenoxyethanol로 마취 후, 비뇨생식공 주위를 가볍게 눌러 오줌과 배설물을
미리 제거하였다. 이후 비뇨생식공 주위를 깨끗이 닦은 다음, 복부를 부드럽게 압박하여 정액을 채취하여 얼음을 채운 ice box에 보관하였다. 채정기간동안 매월 채취된 정액은 개체당 어체중 $100 \mathrm{~g}$ 당 $\mathrm{mL}$ 로 계산하여 나타냈으며, 일부 정액은 일반 혈액분석법인 microhematocrit법을 변형한 spermatocrit 측정 에 사용되었다 (Bouck and Jacobson, 1976).

\section{혈액 채취 및 호르몬분석}

실험어로부터 혈액을 채취하기 이전에 공급한 먹이가 어체의 혈액성상에 미치는 영향을 최소화하기 위하여 채혈 24시간 전부 터 절식시켰다. 채혈은 실험어를 $200 \mathrm{ppm}$ 2-phenoxyethanol로 마취 후, heparin이 처리된 주사기를 사용하여 미부혈관으로부터 채혈하였으며, 원심분리 $\left(4^{\circ} \mathrm{C}, 10,000 \mathrm{rpm}, 5\right.$ 분 $)$ 하여 얻은 혈장은 분석전까지 초저온 냉동고 $\left(-72^{\circ} \mathrm{C}\right)$ 에 보관하였다. 혈중 cortisol, testosterone $(\mathrm{T})$, estradiol-17ß $\left(\mathrm{E}_{2}\right)$ 및 11-ketotestosterone (11-KT) 농도는 각각의 RIA kit (DSL, USA)를 사용하여 Aida et al. (1984) 의 방법에 따라 방사면역측정법 (radioimmunoassay)으로 분석하 였다.

\section{통계처리}

모든 측정값은 평균표준오차로 나타냈으며, 유의차는 SPSS-통계패키지 (version 12.0)를 이용하여 Independent samples t-test와 One-way ANOVA-test (Duncan's multiple range test)에 의해 검정하였다 $(P<0.05)$.

\section{결 과}

\section{GSI}

해수 및 담수 순환여과 사육수조에서 장기간 실내사육한 3 년생 감성돔의 번식기간동안 GSI 변화는 Fig. 1에서 보는 바와 같다. $\mathrm{BSW}$ 의 $\mathrm{GSI}$ 는 2 월의 1.18 에서 3 월의 3.35 로 증가하 여 최대값을 보인 후, 4 월에 0.80 으로 급격히 감소하여 5월과 6월에 각각 $0.37,0.24$ 로 감소하는 경향이었다. $\mathrm{BFW}$ 은 2월에 3.72로 최대값을 보였으며 3월에 3.46으로 비슷한 수준을 보인 후, 4월에 1.72 로 급격히 감소하여 5월과 6 월에 각각 0.40 , 0.38 로 $\mathrm{BSW}$ 과 비슷한 수준으로 감소하는 경향이었다.

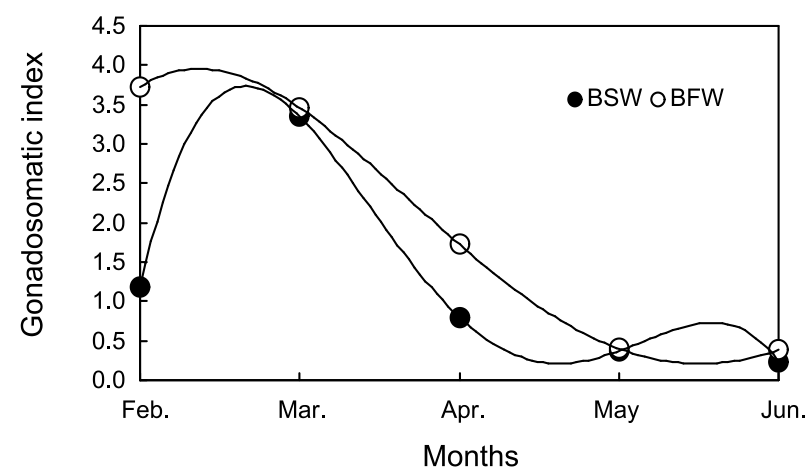

Fig. 1. Gonadosomatic index (GSI) in breeding period of 3-year-old black porgy reared in seawater and freshwater. BSW: black porgy reared in seawater, BFW: black porgy reared in freshwater. 

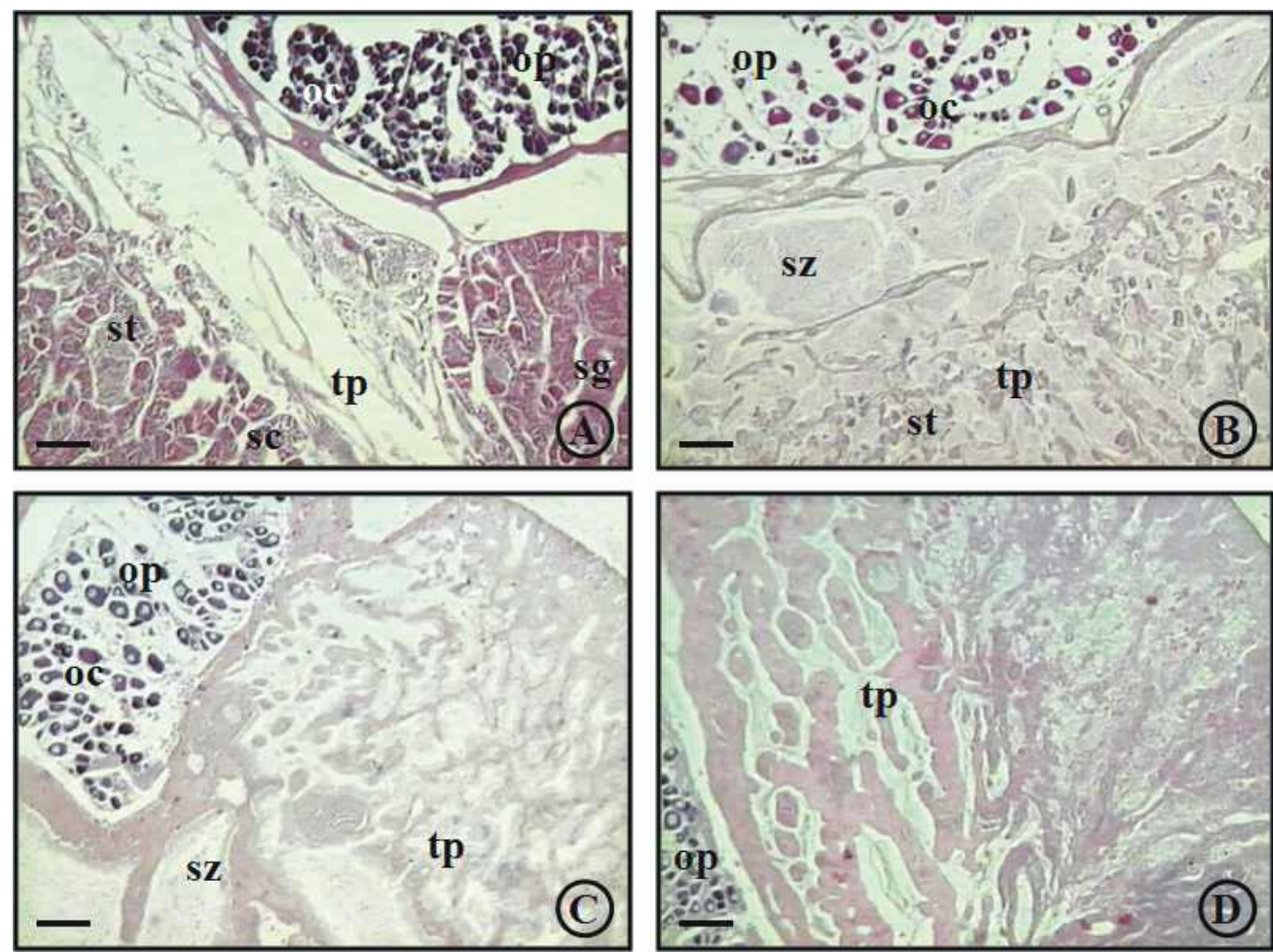

Fig. 2. Transverse sections of gonad from 3-year-old black porgy reared in seawater. A: growing stage (Dec. Feb.); B: mature stage (Feb. Mar.); C: spent stage (Mar. Jun.); D: degeneration and resting stage (Jul. Dec.). oc: oocyte; op: ovary part; sc: spermatocyte; sg: spermatogonis; st: spermatid; sz: spermatozoa, tp: testis part. Scale Bars: $100 \mu \mathrm{m}$.
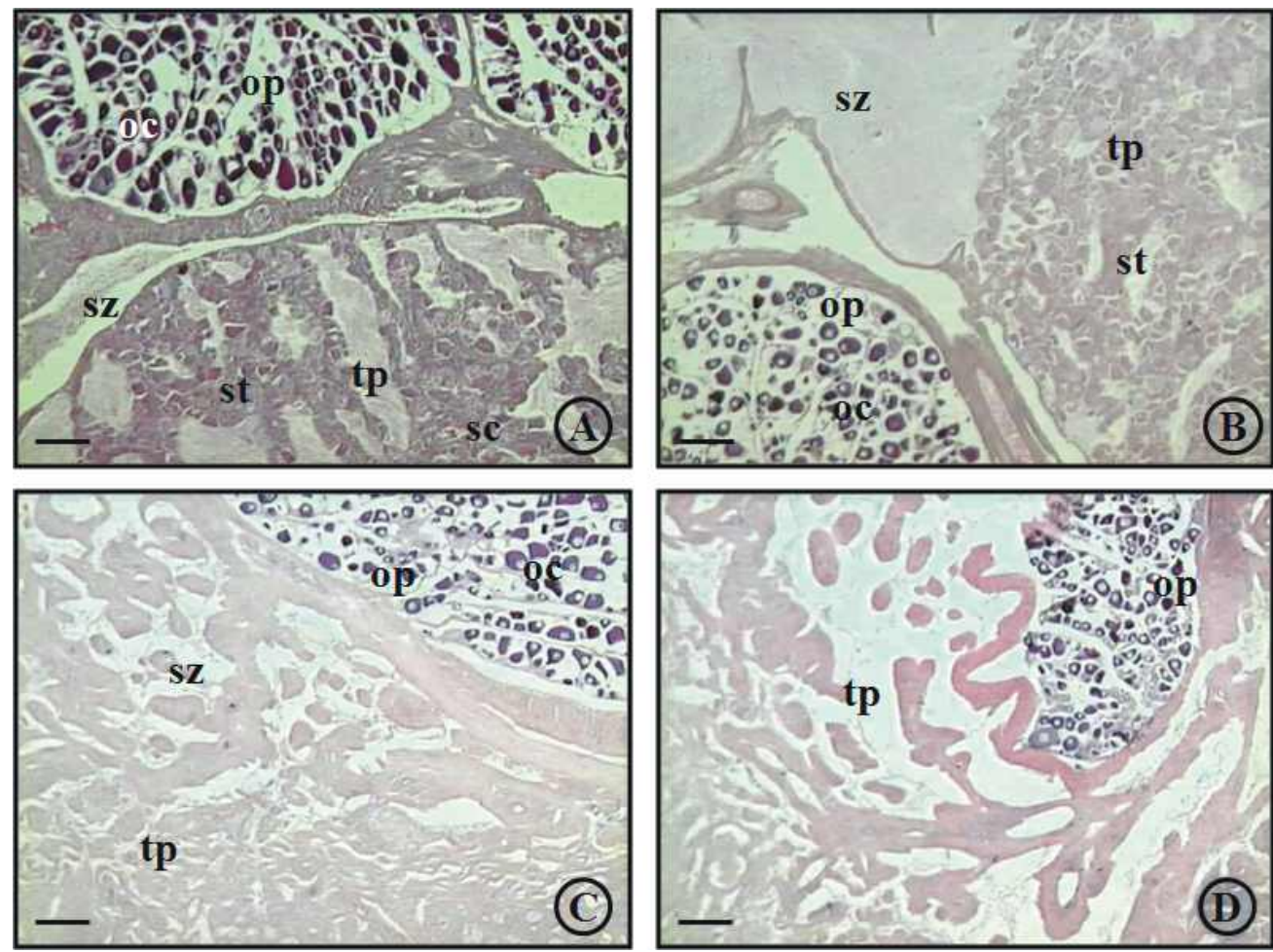

Fig. 3. Transverse sections of gonad from 3-year-old black porgy reared in freshwater. A: growing stage (Nov. Jan.); B: mature stage (Jan. Feb.); C: spent stage (Feb. May); D: degeneration and resting stage (Jun. Nov.). oc: oocyte; op: ovary part; sc: spermatocyte; st: spermatid; sz: spermatozoa, tp: testis part. Scale Bars: $100 \mu \mathrm{m}$. 

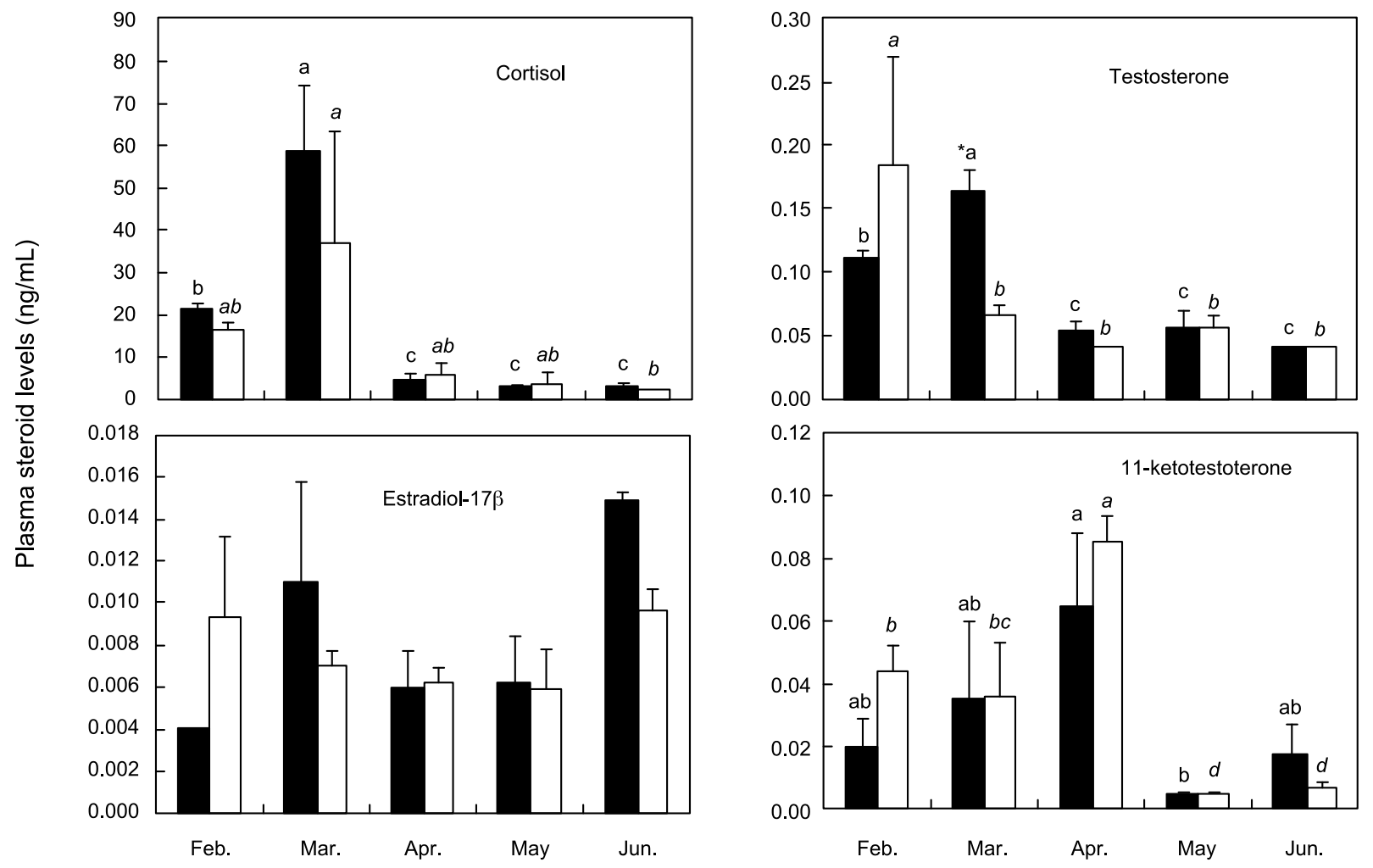

Months

BSW $\square$ BFW

Fig. 4. Plasma steroid levels in breeding period of 3-year-old black porgy reared in seawater and freshwater. BSW: black porgy reared in seawater, BFW: black porgy reared in freshwater. Different small letters significant differences between months at each BSW and BFW $(P<0.05)$. Asterisk show significant differences between BSW and BFW at each months $(P<0.05)$.

\section{생식소의 조직학적 발달}

해수 및 담수 순환여과 사육수조에서 장기간 실내사육한 3 년생 감성돔의 생식소 발달을 조직학적으로 관찰한 결과, 3 년생 BSW과 BFW의 난소부위 발달은 조사기간동안 소엽내 주변인기 단계의 난모세포만이 분포하고 있었으며 더 이상 발달하지 않았다. 그러나 정소부위는 정원세포, 정모세포 및 정세포 등 활발한 정자형성 과정이 진행되어 정자가 방출되었 다 (Fig. 2, 3). 3년생 $\mathrm{BSW}$ 과 $\mathrm{BFW}$ 의 정소발달을 성장기, 성숙 기, 방정기 그리고 퇴화 및 휴지기 등 4단계로 나누어 월별로 비교했을 때, BSW은 12 2월에 성장기, 2 3월에 성숙기, 3 6 월에 방정기, 7 12월에 퇴화 및 휴지기로 나타났으며, BFW은 11 1월에 성장기, 1 2월에 성숙기, 2 5월에 방정기, 6 11월에 퇴화 및 휴지기로 구분되었다.

\section{혈중 cortisol 및 성 스테로이드호르몬 변화}

해수 및 담수 순환여과 사육수조에서 장기간 실내사육한 3 년생 감성돔의 번식기간동안 혈중 cortisol 및 성 스테로이드 호르몬 농도의 변화는 Fig. 4에서 보는 바와 같다. BSW과

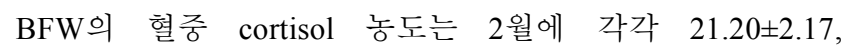
$16.17 \pm 3.85 \mathrm{ng} / \mathrm{mL}$ 에서 3 월에 각각 $58.60 \pm 22.49,37.00 \pm 37.76$ $\mathrm{ng} / \mathrm{mL}$ 로 유의한 차이를 보이며 증가하였다가, 4 월에 각각 $4.23 \pm 3.63,5.93 \pm 4.75 \mathrm{ng} / \mathrm{mL}$ 으로 유의한 차이로 감소하여 번식 이 끝나는 6 월까지 유지되었다 $(P<0.05) . \mathrm{BSW}$ 의 혈중 $\mathrm{E}_{2}$ 농도는 2월에 $0.0040 \pm 0.0000 \mathrm{ng} / \mathrm{mL}$ 에서 3 월에 $0.0109 \pm 0.0084$ $\mathrm{ng} / \mathrm{mL}$ 로 증가하였다가 4월에 $0.0059 \pm 0.0026 \mathrm{ng} / \mathrm{mL}$ 로 다시 감소한 후, 6월에 $0.0148 \pm 0.0007 \mathrm{ng} / \mathrm{mL}$ 로 증가하는 경향을 보였으나 유의한 차이는 없었다. $\mathrm{BFW}$ 의 혈중 $\mathrm{E}_{2}$ 농도는 2 월에 $0.0094 \pm 0.0053 \mathrm{ng} / \mathrm{mL}$ 에서 3월에 $0.0069 \pm 0.0014 \mathrm{ng} / \mathrm{mL}$ 로 감소 하여 5월까지 $0.0059 \pm 0.0027 \mathrm{ng} / \mathrm{mL}$ 로 비슷한 수준을 유지하 다가 6월에 $0.0096 \pm 0.0016 \mathrm{ng} / \mathrm{mL}$ 로 다시 증가하는 경향을 보 였으나 유의한 차이는 없었다 $(P<0.05)$. $\mathrm{BSW}$ 의 혈중 $\mathrm{T}$ 농도 는 2월의 $0.1100 \pm 0.0115 \mathrm{ng} / \mathrm{mL}$ 에서 3 월의 $0.1633 \pm 0.0306$ $\mathrm{ng} / \mathrm{mL}$ 로 유의하게 증가하였다가 4월의 $0.0533 \pm 0.0153 \mathrm{ng} / \mathrm{mL}$ 로 유의하게 감소하여 6월까지 낮은 수준을 유지하였다. $\mathrm{BFW}$ 의 혈중 $\mathrm{T}$ 농도는 2월에 $0.1850 \pm 0.1202 \mathrm{ng} / \mathrm{mL}$ 로 높은 수준을 보인 후 3월에 $0.0650 \pm 0.0173 \mathrm{ng} / \mathrm{mL}$ 로 유의하게 감소하여 6월 까지 낮은 수준을 유지하였다 $(P<0.05)$. BSW과 $\mathrm{BFW}$ 의 혈중 
$11-\mathrm{KT}$ 농도는 2월에 각각 $0.0196 \pm 0.0157,0.0441 \pm 0.0140$ $\mathrm{ng} / \mathrm{mL}$ 였던 것이 이후 점차 증가하여 4월에 각각 $0.0646 \pm$ $0.0410,0.0850 \pm 0.0140 \mathrm{ng} / \mathrm{mL}$ 로 다른 월보다 유의하게 높은 수준을 나타냈으나, 5월에는 각각 $0.0044 \pm 0.0011,0.0044 \pm$ $0.0021 \mathrm{ng} / \mathrm{mL}$ 로 급격히 감소하여 6월까지 낮은 수준을 유지하 였다 $(P<0.05)$.

\section{Spermatocrit 및 채정량}

해수 및 담수 순환여과 사육수조에서 장기간 실내사육한 3 년생 감성돔의 번식기간동안 월별 spermatocrit 및 채정량은 Fig. 5 에서 보는 바와 같다. BSW의 채정 가능시기는 3 월부터 6월까지였으며, 채정된 정액의 월별 spermatocrit는 98.3 98.9 로 유의한 차이를 보이지 않았다 $(P<0.05)$. 어체중 $100 \mathrm{~g}$ 당 평균 채정량은 3 월부터 6 월까지 각각 $0.18,0.38,1.02,0.71$ $\mathrm{mL}$ 로 3월부터 증가하여 5월에 최대 채정량을 보인 후 6월에 감소하여 7월에는 채정이 이루어지지 않았다. $\mathrm{BFW}$ 의 채정 가능시기는 BSW 보다 1 개월 빠른 2월부터 5 월까지였으며, 채정된 정액의 월별 spermatocrit는 97.8 99.5로 2월에 채정한 정액의 spermatocrit가 4월과 5월에 채정한 정액의 spermatocrit 보다 유의하게 낮았다 $(P<0.05)$. 어체중 $100 \mathrm{~g}$ 당 평균 채정량 은 2월부터 5월까지 각각 $0.21,0.56,0.66,0.33 \mathrm{~mL}$ 로 2월부터 채정량은 서서히 증가하여 4월에 최대 채정량을 보인 다음, 5 월에 감소하여 6 월에는 채정이 이루어지지 않았다.
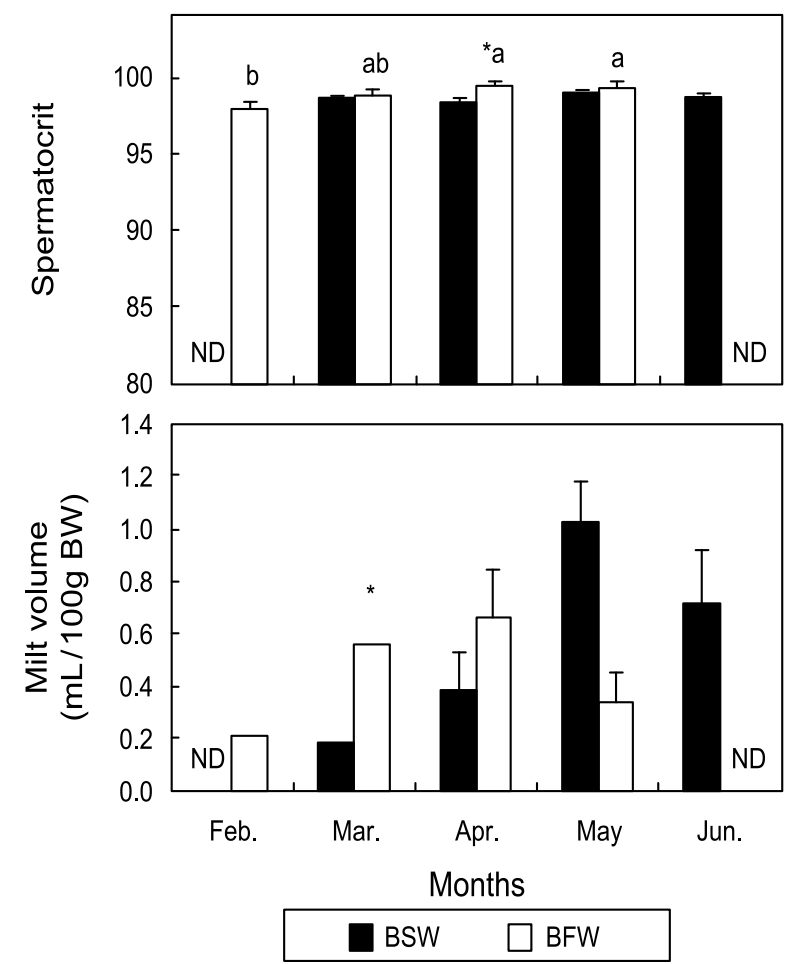

Fig. 5. Spermatocrit and milt volume per $100 \mathrm{~g}$ body weight (BW) in breeding period of 3 -year-old black porgy reared in seawater and freshwater. Other details as Fig. 4.

\section{고 찰}

일반적으로 어류의 산란시기를 계절에 따라 봄, 여름, 가을, 겨울, 봄여름 그리고 봄가을 산란형 등 6가지로 나누고 있다 (Aida, 1991). Hwang (1999)의 연구에서 감성돔의 GSI와 성 스테로이드호르몬의 변화로 보아 봄여름 산란형에 속한다고 하였으며, 자연수온 $\left(9.6 \sim 25.8^{\circ} \mathrm{C}\right)$ 에 가까운 환경에서 사육한 감성돔의 생식주기는 2 3월에 성장기, 3 4월에 성숙기, 5 6월 에 산란기, 7 1월에 퇴화 및 휴지기로 연속적인 4단계를 보인 다고 하였다. 본 연구에서 번식기간동안 실내사육한 $\mathrm{BSW}$ 의 $\mathrm{GSI}$ 는 2 3월에 증가하여 3 4월에 감소하는 경향을 보였으며, $\mathrm{BFW}$ 은 이미 2월에 GSI가 최고값을 보인 후 3월부터 감소하는 경향을 보였다. 그리고 생식소의 조직학적 관찰 결과에서도 $\mathrm{BSW}$ 은 12 2월에 성장기, 2 3월에 성숙기, 3 6월에 방정기, 7 12월에 퇴화 및 휴지기의 조직상을 보였으며, BFW은 11 1 월에 성장기, 1 2월에 성숙기, 2 5월에 방정기, 6 11월에 퇴화 및 휴지기의 조직상을 보여, 실내사육한 $\mathrm{BSW}$ 뿐만 아니라 $\mathrm{BFW}$ 역시 봄여름 산란형에 속한다는 것을 알 수 있었다.

$\operatorname{Lim}$ (1998)에 의하면 감성돔은 3월부터 성숙 후기의 정소를 가진 개체가 출현하였으며, 4 월부터는 정액을 방출하는 개체 가 나타나기 시작하여 5 월에는 대부분의 개체에서 방정이 이루어졌다고 하였다. 본 연구의 $\mathrm{BSW}$ 에서는 3월부터 채정 가능 개체가 나타나기 시작하여 5월에 대부분의 개체에서 채정이 이루어졌으며, 6월까지 지속되었다. $\mathrm{BFW}$ 의 경우 $\mathrm{BSW}$ 보다 1개월 빠른 2월부터 채정 가능하였으며, 4 5월에 대부분의 개체에서 채정이 이루어졌다. 이러한 결과는 본 연 구에서 사용한 $\mathrm{BSW}$ 과 $\mathrm{BFW}$ 의 사육수온이 약 $20^{\circ} \mathrm{C}$ 전후로 일정하게 유지되는 실내에서 사육하였기 때문에 자연수온에 서 감성돔의 산란기인 5 6월보다 빠른 2월부터 산란기가 시작 되었다고 판단되며, 사육수온이 일정하게 유지되는 실내에서 사육한 $\mathrm{BSW}$ 과 $\mathrm{BFW}$ 이라 할지라도 본래의 번식특성은 변하 지 않는 것으로 판단된다. 또한 $\mathrm{BFW}$ 의 생식주기 및 채정시기 가 $\mathrm{BSW}$ 보다 약 1 개월 정도 빠른 결과를 나타냈다. Chang et al. (1996)은 염분별 숭어의 성장 연구에서 체액과 등장 (300 390 mOsm/kg)인 해수에서 성장이 가장 좋았으며, 이는 체액과 등장의 매질에서 삼투압조절 에너지가 적게 소모되기 때문에, 절약된 에너지만큼이 성장에 동원되었을 거라고 하였 다. 또한 Morgan and Iwama (1991)는 어류의 성장에 있어 염분의 영향은 흔히 삼투압 및 이온 조절에 소비되는 에너지 가 적게 드는 염분에서 가장 양호한 성장을 할 수 있다고 하였다. 즉 삼투압조절을 위한 에너지가 가장 적게 소비되는 염분범위가 최적의 성장조건이라는 것을 의미한다. 이와 같은 추론에 근거하여 감성돔 체액의 삼투질농도 (340 390 $\mathrm{mOsm} / \mathrm{kg}$ )는 해수 (약 $1,000 \mathrm{mOsm} / \mathrm{kg}$ ) 보다 담수 (100 $\mathrm{mOsm} / \mathrm{kg}$ 이하)에 가깝기 때문에, $\mathrm{BSW}$ 보다 삼투압조절 에너 지가 적게 드는 $\mathrm{BFW}$ 이 생식소의 성장과 성숙에 보다 많은 에너지를 동원하여 GSI, 생식주기 및 채정시기 등을 앞당긴 것으로 간주된다.

일반적으로 경골어류의 안정시 혈중 cortisol 농도는 연어과 
어류 30 40 ng/mL (Pickering and Pottinger, 1989), 나일틸라피 아 Oreochromis niloticus 5 50 ng/mL (Auperin et al., 1997)이 며, 본 연구의 실험어와 같은 감성돔의 경우 $10 \sim 35 \mathrm{ng} / \mathrm{mL}$ (Chang et al., 2002; Min et al., 2003, 2005a)라고 보고하였다. 본 연구에서 번식기간동안 $\mathrm{BSW}$ 와 $\mathrm{BFW}$ 의 혈중 cortisol 농도 는 3월만 안정시 보다 높은 수준을 보였으며, 그 외에는 안정시 수준을 유지하였다. Lee et al. (2004)의 연구보고에 의하면 감성돔의 경우, 혈중 cortisol은 시상하부의 신경세포를 자극하 여 생식소자극호르몬 방출호르몬 (gonadotropin releasing hormone, GnRH) 분비에 직접적인 효과가 있다고 하였다. 본 연구에서 혈중 cortisol 농도가 안정시 수준보다 높았던 3월은 $\mathrm{BSW}$ 와 $\mathrm{BFW}$ 의 채정이 가능하게 된 시기로 혈중 cortisol 농도 의 증가가 감성돔의 정소발달 및 정자형성을 가속화 시킨 후, 방정이 개시되자 감소한 것으로 판단된다. 혈중 $\mathrm{T}$ 농도는 정자형성기 동안 증가하다가 정자배정기가 시작되면서 감소 하고, 혈중 11-KT 농도는 정자배정기 때 높은 농도를 유지하다 가 이후 감소하기 시작한다고 보고하였다 (Fostier et al., 1983). 정어리 Sardinops melanostictus의 경우 혈중 11-KT 농도는 전 기간동안 측정되지 않은 반면, 혈중 $\mathrm{T}$ 농도는 정자형성기 때 점차 증가하여 정자배정기 때 최고 농도를 보였다 (Matsuyama et al., 1991). 황놀래기 Pseudolabrus japonicus는 방정직전 혈중 11-KT 농도는 증가하다가 정자배정기 때 감소 하였다 (Morita et al., 1997). 대서양 대구 Gadus morhus와 독가시치류인 Siganus guttatus에서 혈중 T와 11-KT 농도는 번식기간동안 같은 경향으로 증가하여 정자배정기 때 최고 농도를 보였다 (Rahman et al., 2000; Dahle et al., 2003). 문절망 둑 Acanthogobius flavimanus 의 경우 혈중 $\mathrm{T}$ 는 정자형성뿐만 아니라 정자배정에도 관여하며, 혈중 11-KT는 정자배정에만 관여한다고 보고하였다 (Park et al., 2005). 본 연구에서 BFW 의 혈중 $\mathrm{T}$ 농도는 2 월에, $\mathrm{BSW}$ 는 3 월에 가장 높은 농도를 보인 후 감소하였는데, 이는 $\mathrm{BSW}$ 와 $\mathrm{BFW}$ 의 최초 채정 가능시 기와 일치하는 결과로 감성돔에서 혈중 $\mathrm{T}$ 는 정자형성에 관여 하는 것으로 판단된다. 또한 $\mathrm{BSW}$ 의 혈중 $11-\mathrm{KT}$ 농도는 2월부 터 점차 증가하여 4월에 최고 농도를 보인 후 급격히 감소하였 으며, BFW은 2월과 3월에 비슷한 수준의 농도를 보였으며 4월에 최고 농도를 보인 후 급격히 감소하였다. 이러한 월별 혈중 11-KT 농도 증가는 $\mathrm{BFW}$ 의 4월 농도변화를 제외하고는 다음달 각각의 채정량 증가와 비슷한 경향을 보여 $\mathrm{BSW}$ 와 $\mathrm{BFW}$ 에 있어 혈중 $11-\mathrm{KT}$ 는 정자배정에 관여하는 것으로 판단 된다. Lee et al. (2001)은 성 전환하지 않은 3 년생 감성돔의 경우, 혈중 11-KT 농도는 3 4월에, 혈중 $\mathrm{E}_{2}$ 농도는 10 11월에 최고값을 보임으로써, 혈중 $\mathrm{E}_{2}$ 의 작용이 혈중 $\mathrm{T}$ 나 11-KT에 비해 빠른 것으로 보고하였다. Min et al. (2005b)은 감성돔의 혈중 $\mathrm{E}_{2}$ 작용이 혈중 $\mathrm{T}$ 작용보다 빠른 이유를 첫째 성 전환을 위하여 혈중 $\mathrm{E}_{2}$ 에 의해 난모세포를 성숙시켜야 할 필요성이 있기 때문이며, 둘째 정자형성시기 이전에 혈중 $\mathrm{E}_{2}$ 가 분비되 게 함으로써 수컷의 기능에만 충실하기 위한 감성돔의 번식전 략으로 해석했다. 본 연구에서 3 년생 $\mathrm{BSW}$ 와 $\mathrm{BFW}$ 의 혈중 $\mathrm{E}_{2}$ 농도는 번식기간동안 큰 차이를 보아지 않아, 이 기간에
혈중 $\mathrm{E}_{2}$ 는 생식소발달 및 정자형성에 관여하지 않는 것으로 판단된다.

이상 해수 및 담수환경에서 장기간 사육한 3년생 수컷 감성 돔의 번식기간동안 생식소발달, 성 스테로이드호르몬의 변화, 채정시기 및 채정량 등을 조사한 결과를 종합해 볼 때, $\mathrm{BFW}$ 이 $\mathrm{BSW}$ 보다 생식주기가 1 개월 빠른 것으로 판단된다. 이는 $\mathrm{BSW}$ 보다 삼투압조절에 소비되는 에너지가 적게 드는 $\mathrm{BFW}$ 이 생식소의 성장, 성숙 및 배정에 관여하는 성 스테로이드호 르몬을 분비하는데 보다 많은 에너지를 공급하여 생식주기를 앞당겼을 거라고 추정된다. 또한 담수환경에서 장기간 사육한 감성돔이라 할지라도 본래의 생식주기 및 정자형성 등 번식과 관련된 기본특성은 변하지 않는 것으로 판단된다.

$$
\text { 사 사 }
$$

본 연구는 한국과학재단 목적기초연구 (과제번호: R012004-000-10251-0)와 국립수산과학원 경상과제 (RP-2010-AQ075) 지원으로 수행되었습니다.

\section{참고문헌}

Aida K. 1991. Environmental regulation of reproduction rhythms in teleosts. Bull Inst Zool. Academia Sinica, Monograph, 16, 173-187.

Aida K, Kato T and Awaji M. 1984. Effect of castration on the smoltification of precocious male masu salmon, Oncorhynchus masou. Bull Jap Inst Zool. Academia Sinica, Bull Jpn Soc Sci Fish 50, 565-571.

Auperin B, Baroiller JF, Ricordel MJ, Fostier A and Prunet P. 1997. Effect of confinement stress on circulation levels of growth hormone and two prolactins in freshwater-adapted tilapia, Oreochromis niloticus (T). Gen Comp Endocrinol 108, 35-44.

Bouck GR and Jacobson J. 1976. Estimation of salmonid sperm concentration by microhematocrit technique. Trans Am Fish Soc 105, 534-535.

Chang YJ and Hur JW. 1999. Physiological responses of grey mullets (Mugil cephalus) and Nile tilapia (Oreochromis niloticus) by rapid changes in salinity of rearing water. J Korean Fish Soc 32, 310-316.

Chang YJ, Min BH and Choi CY. 2007. Black porgy (Acanthopagrus schlegeli) prolactin cDNA sequence: mRNA expression and blood physiological responses during freshwater acclimation. Comp Biochem Physiol B 147, 122-128.

Chang YJ, Min BH, Chang HJ and Hur JW. 2002. Comparison of blood physiology in black seabream (Acanthopagrus schlegeli) cultured in converted freshwater from seawater and seawater from freshwater. J Korean Fish Soc 35, 595-600. 
Chang YJ, Lee YC and Lee BK. 1996. Comparison of growth and survival rates of juvenile grey mullets (Mugil cephalus) in different salinities. J Aquaculture 9, 311-320.

Choi CY, Min BH, Jo PG and Chang YJ. 2007. Molecular cloning of PEPCK and stress response of black porgy (Acanthopagrus schlegeli) to increased temperature in freshwater and seawater. Gen Comp Endocrinol 152, 47-53.

Choe MK and Yeo IK. 2002. Studies on the salinity tolerance of juvenile rainbow trout, Oncorhynchus mykiss. Korean J Ichthyol 14, 205-211.

Dahle R, Taranger GL, Karlsen O, Kjesbu OS and Norberg B. 2003. Gonadal development and associated changes in liver size and sexual steroids during the reproduction cycle of captive male and female atlantic cod (Gadus morhua L.). Comp Biochem Physiol A 136, 641-653.

Fostier A, Jalabert B, Billard R, Breton B and Zohar Y. 1983. The gonadal steroids. In: Fish physiology, Vol. IX/A: Reprodcution Hoar WS, Randall DJ and Donaldson EM, eds. Academic Press, New York, U.S.A. 277-372.

Han HK, Kang DY, Jun CY and Chang YJ. 2003. Effect of salinity change on physiological response and growth of yearling sea bass, Lateolabrax japonicus. J Aquaculture 16, 31-36.

Hwang SI. 1999. Artificial control in sex and reproductive cycle of black seabream, Acanthopagrus schlegeli. Ph.D. Thesis, Cheju National University, Cheju, Korea, 120.

Jeong MH, Kim YS, Min BH and Chang YJ. 2007. Effect of fish number in respiratory chamber on routine oxygen consumption of black porgy Acanthopagrus schlegeli reared in seawater or freshwater. J Aquaculture 20, 121-126.

Kim YS, Do YH, Min BH, Lim HK, Lee BK and Chang YJ. 2009. Physiological responses of starry flounder Platichthys stellatus during freshwater acclimation with different speeds in salinity change. J Aquaculture 22, 28-33.

Lee YH, Du JL, Yueh WS, Lin BY, Huang JD, Lee CY, Lee MF, Lau EL, Lee FY, Morrey C, Nagahama $\mathrm{Y}$ and Chang CF. 2001. Sex change in the protandrous black porgy, Acanthopagrus schlegeli: a review in gonadal development, estradiol, estrogen receptor, aromatase activity and gonadotropin. J Exp Zool 290, 715-726.

Lee YH, Du JL, Shih YS, Jeng SR, Sun LT and Chang
CF. 2004. In vivo and in vitro sex steroids stimulate seabream gonadotropin-releasing hormone content and release in the protandrous black porgy, Acanthopagrus schlegeli. Gen Comp Endocrinol 139, 12-19.

Lim HK. 1998. Physiological properties of the sperm and gamete preservation in black seabream, Acanthopagrus schlegeli. Ph.D. Thesis, Pukyong National University, Busan, Korea, 130.

Matsuyama M, Adachi S, Nagahama Y, Kitajima C and Matsuura S. 1991. Testicular development and serum levels of gonadal steroids during the annual reproductive cycle of captive japanese serdine. Japan J Ichthyol 37, 381-390.

Min BH, Kim BK, Hur JW, Bang IC, Byun SK, Choi CY and Chang YJ. 2003. Physiological responses during freshwater acclimation of seawater-cultured black porgy (Acanthopagrus schlegeli). Korean J Ichthyol 15, 265-275.

Min BH, Choi CY and Chang YJ. 2005a. Comparison of physiological conditions on black porgy, Acanthopagrus schlegeli acclimated and reared in freshwater and seawater. J Aquaculture 18, 37-44.

Min BH, Noh GA, Jeong MH, Kang DY, Choi CY, Bang IC and Chang YJ. 2006b. Effects of oral administration of thyroid hormone on physiological activity and growth of black porgy reared in freshwater or seawater. J Aquaculture 19, 149-156.

Min BH, Noh GA, Jeong MH and Chang YJ. 2005b. Effects of 3,5,3'-triiodo-L-thyronine $\left(\mathrm{T}_{3}\right)$ on sex steroid levels and gonadal development in black porgy, Acanthopagrus schlegeli. Dev Reprod 9, 15-22.

Min BH, Bang IC, Choi WS and Chang YJ. 2006c. Evaluation of fish flesh and profitability of black porgy (Acanthopagrus schlegeli) cultured in freshwater. J Aquaculture 19, 14-18.

Min BH, Jeong MH, Noh GA, Lim HK, Choi CY and Chang YJ. 2006a. Hyposmotic treatment for control of the parasitic copepod, Alella macrotrachelus on the gill of cultured black porgy. J Aquaculture 19, 19-24.

Morgan JD and Iwama GK, 1991. Effects of salinity on growth, metabolism, and ion regulation in juvenile rainbow and steelhead trout (Oncorhynchus mykiss) and fall chinook salmon (Oncorhynchus tshawytscha). Can J Fish Aquat Sci 48, 2083-2094.

Morita S, Matsuyama M and Kashiwagi M. 1997. Seasonal changes of gonadal histology and serum 
steroid hormone levels in the bambooleaf wrasse, Pseudolabrus japonicus. Nippon Suisan Gakkaishi 63, 694-700.

Park MH, Hwang IJ, Kim DJ, Lee YD. Kim HB and Bark HJ. 2005. Gonadal development and sex steroid hormone levels of the yellowfin goby, Acanthogobius flavimanus. J Korean Fish Soc 38, 309-315.

Pickering AD and Pottinger TG. 1989. Stress responses and disease resistance in salmonid fish: Effect of chronic elevation of plasma cortisol. Fish Physiol Biochem 7, 253-258.

Rahman MD, Takemura A and Takano K. 2000. Annual changes in testicular activity and plasma steroid hormones in the gold rabbitfish, Siganus guttatus (bloch). Fish Sci 66, 894-900.

Yoon HD, Suh SB, Kim YS, and Lee JH. 1996. Model test on the loss of experimental fishy odor in tilapia, Oreochromis niloticus, by sea water acclimation. J Korean Fish Soc 29, 431-437.

$\begin{array}{rrr}\text { 2010년 } & \text { 7월 } & \text { 8일 접수 } \\ \text { 2010년 } & \text { 9월 } & \text { 6일 수정 } \\ \text { 2010년 } & \text { 10월 } & 11 \text { 일 수리 }\end{array}$

2010년 10월 11일 수리 